\title{
Universiteit Stellenbosch
}

\section{Vervreemding en gawe - Sleutelmotiewe in die Heidelbergse Kategismus? ${ }^{1}$}

\section{ABSTRACT \\ Alienation and gift - Key motifs in the Heidelberg Catechism?}

The paper deals with two forms of contemporary criticism widely directed against the threefold logic of the Heidelberg Catechism, namely against the so-called pessimistic anthropology and moralism presupposed by the focus on human sin in the first part of the Catechism, according to popular accusations, and the so-called legalistic use of the category of gratitude as motivation for Christian life and worship in the third part of the Catechism, according to other popular accusations. In a first section, the thrust of these forms of critique is briefly explained. A second section responds to the first accusation by considering the first part of the Catechism and the way it deals with human misery as alienation. The third and final section responds to the second accusation by considering the last part of the Catechism and the way it deals with gratitude as an integral part of the comfort, not merely as reciprocal human response to the comfort.

\section{Miseria et Misericordia?}

1. Die Heidelbergse Kategismus het van meet af sowel groot waardering as skerp kritiek ontvang. Die waardering het onder andere te make gehad met die pastorale aanslag, wat op talle maniere duidelik word, vanaf die diep persoonlike eerste vraag en antwoord, maar ook uit die bekende driedeling waarin dié eksistensiële troos dan uiteengesit word. ${ }^{2}$ In 1938 sou Karl Barth nog dié waardering verwoord as hy sê: "The outline human misery - human redemption - human gratitude is in its simplicity an ingenious restatement of the essence of

1. Hierdie voordrag is oorspronklik gelewer as openingstoespraak tydens die teologiese dag van die fakulteit teologie, Stellenbosch, op 4 Februarie 2013. Die titel was ook die oorkoepelende tema van die teologiese dag. Dit is gewy aan 'n herdenking van die Heidelbergse Kategismus se 450-ste bestaansjaar.

2. Vir 'n baie verhelderende bespreking van die Heidelbergse Kategismus as Protestantse belydenisskrif, teen sy historiese agtergrond en met sy teologiese beslissings, insluitende sy struktuur en pastorale opbou, sien W. D. Jonker, Bevrydende Waarheid, Wellington: Bybelmedia, 1998. Daar bestaan uiteraard 'n oorvloed materiaal oor die Kategismus, sowel historiese studies as kategetiese en homiletiese uitlegte. Vir een bekende voorbeeld, sien Th. L. Haitjema, De Heidelbergse Catechismus als Klankbodem en Inhoud van het actuele Belijden onzer Kerk, Wageningen: H. Veenman en Zonen N.V., 1962. Vyftig jaar gelede het heelwat goeie studies byvoorbeeld verskyn rondom die 400-jarige herdenking, in 1963. Vir 'n effens ouer maar steeds waardevolle bundel opstelle, sien daarom Bard Thompson, Hendrikus Berkhof, Eduard Schweizer \& Howard G. Hageman se bundel uit dié tyd, Essays on the Heidelberg Catechism, Philadelphia: United Church Press. Met die oog op die herdenking vanjaar gebeur dieselfde weer, sien reeds Georg Plasger, Glauben heute mit dem Heidelberger Katechismus, Göttingen: Vandenhoeck \& Ruprecht, 2012 en Martin Heimbucher, Christoph Schneider-Harpprecht \& Aleida Siller (Hrsg.), Zugänge zum Heidelberger Katechismus. Geschichte - Themen - Unterricht, Neukirchen: Neukirchener Verlag, 2012 . 
NGTT: Oopbron - http://ngtt.journals.ac.za

the whole Reformation." ${ }^{3}$

2. Die kritiek teen die Kategismus, hoewel ook gemik teen kleinere aspekte van die inhoud, ${ }^{4}$ sou meermale juis óók gerig word teen hierdie driedeling. Van die verbreide hedendaagse kritiek is dat dié driedeling nie langer relevant is nie, dat dit nie langer die lewensgevoel van mense aanspreek nie, dat dit nie meer sinvol verkondig en geglo kan word gegee die tydsgees vandag nie. Dié kritiek teen die opbou van die Kategismus sluit meerdere verwyte in en word by geleentheid gerig teen álle aspekte van die Kategismus se logika en daarmee teen ál drie die onderdele. Ons tydsgees ken nie meer só n sondebesef en skuldgevoel nie. Die lewensgevoel vandag het nie meer behoefte aan dié soort vergiffenis, vryspraak en regverdiging nie. Hedendaagse mense ervaar die oproep tot dankbaarheid - wat boonop tot uiting kom in gebod en gebed - as wetties en in stryd met hulle eie behoefte aan individuele vryheid.

3. Op al dié verwyte sou noukeuriger ingegaan moes word, sowel om die eintlike besware beter te verstaan as om te oorweeg of hulle inderdaad oortuigend is, maar tyd en ruimte laat dit nie vandag toe nie. Hier word slegs aandag gegee aan spesifieke maniere waarop die kritiek teen die eerste en die laaste dele van die Kategismus dikwels vandag geformuleer word, omdat albei dié soort formulerings inderdaad fundamentele vrae rig aan die diepste veronderstellinge waarop die hele logika van die Kategismus berus.

Die eerste beskuldiging is dat die Kategismus 'n pessimistiese mensbeeld veronderstel, wat nie pas by $n$ hedendaagse, optimistiese siening van die mens nie. Mense word hier voorgestel as van nature geneig tot alle kwaad, wat eenvoudig empiries nie waar is nie. Dit is sielkundig net nie meer moontlik, verstandig of verantwoordelik om mense eers te probeer oortuig van hulle sonde en skuld, alvorens die evangelie as goeie nuus aan hulle gebring sou kon word nie. Ten einde die evangelie geloofwaardig, oortuigend en suksesvol te kan verkondig moet mense anders benader word, moet op ander behoeftes in mense appelleer word, moet die inhoud van die evangelie ook anders voorgestel word as troos en vryspraak, word beweer. Mense is vandag eerder op soek na geluk, welbehae en welvaart, vervulling en sukses, en daarom moet die evangelie eerder verkondig word in terme van happiness-, well-being-, prosperity-

3. Karl Barth, Learning Jesus Christ through the Heidelberg Catechism, Grand Rapids: Wm. B. Eerdmans, 1964, 122. Dié bundel bevat Barth se bekende twee geskrifte oor die Kategismus, te wete sy Einführung in den Heidelberger Katechismus aan Switserse predikante in 1938, waaruit hierdie aanhaling kom, asook sy langer Die christliche Lehre nach dem Heidelberger Katechismus, sy reeks voorlesings in Bonn, direk na die Oorlog in 1947. Albei is vertaal deur Shirley C. Guthrie en die publikasie val ook saam met die 400-jarige herdenking in 1963. Vir 'n informatiewe opstel oor Barth en die Heidelbergse Kategismus, sien die kerkhistoriese studie van Hanna Reichel, onder leiding van Christoph Strohm by Heidelberg, "Was ist dein einziger Trost im Leben und im Sterben? Karl Barths kontextuelle Interpretation des Heidelberger Katechismus," somersemester 2010, beskikbaar by http:/www.heidelberger-katechismus.net/7316-0-22750.html.

4. Die kritiek op die temas en die detail hang uiteraard saam met die sienings van die betrokke kritici. Sommige van die sake wat dikwels aandag kry is byvoorbeeld die verwerping van die mis in Vraag 80 , wat egter later en om polemiese redes ingevoeg is, nie regtig in die logika pas nie en daarom ook deur baie gereformeerde kerke nie as deel van die teks hanteer word nie, omdat hulle die oorspronklike weergawes benut; die siening van die werking van die sakramente, wat weer deel was en bly van die groter konfessionele meningsverskille daaroor; die voorsienigheidsleer met sy oënskynlik kousale formulerings; die tipies gereformeerde leer van die extra Calvinisticum, oor Jesus na sy menslike natuur; en die sterk Anselmiaanse rasionaal waarom ons 'n Middelaar benodig wat tegelyk God en mens is. Sien byvoorbeeld die reeks radiopraatjies wat A. F. N. Lekkerkerker in 1963 in Nederland oor die Kategismus gehou het en waarin hy op vele besware vanuit die destydse tydsgees ingaan, Gesprekken over de Heidelberger, Wageningen: N. V. Gebr. Zomer \& Keunings Uitgeversmaatschappij, 1964. 
en flourishing-taal as in terme van sonde en skuld. Vanaf populêre tot akademiese, vanaf sielkundige tot politieke, vanaf ekonomiese tot kerklike diskoerse word dié soort taal daarom inderdaad vandag met groot entoesiasme en gevolg benut - en in die lig daarvan is die pessimistiese veronderstellings en voorstellings van die Kategismus net nie langer houdbaar en relevant nie, volgens vele. ${ }^{5}$

Die tweede beskuldiging is dat dankbaarheid nie kan dien as motivering vir die Christelike lewe nie. Ook dié beswaar is uiteraard oud en het die verkondiging van die evangelie as kritiek begelei vanaf die eerste oomblikke - by Paulus, soos by Augustinus, soos tydens die Reformasie. Dis belangrik om te onthou dat ook die Lutherse tradisie nie dié oortuiging van die gereformeerde lewensgevoel deel nie, en dat selfs Karl Barth aan die einde van die vierde deel van sy Kirchliche Dogmatik, wanneer hy bedink watter term die implikasies van die versoening in Christus vir die Christelike lewe die beste kan saamvat, ook dankbaarheid oorweeg, en dan tog daartéén besluit, om te kies vir aanroep van God, in sy nadoods gepubliseerde The Christian Life. ${ }^{6}$ Die verbreide hedendaagse kritiek is egter van $\mathrm{n}$ ander aard en kom op vanuit in ander wortel.

Dalk kan hierdie hedendaagse besware die beste saamgevat word in die bekende kritiese vraag: Can a gift be given? Is daar hoegenaamd iets soos n gawe, 'n geskenk, denkbaar, voorstelbaar, moontlik? Dié vraag boei geleerdes toenemend deur die 20ste eeu, in vele akademiese dissiplines, vanaf antropologie tot ekonomie, vanaf sielkunde tot sosiologie. Die Franse antropoloog Marcel Mauss het dié vrae begin oproep met sy studies wat sou aantoon hoe fundamenteel die gee van geskenke is in vele verhoudings. Hulle konstitueer as 't ware ons lewe in gemeenskap en daarmee alle sosiale en ekonomiese verhoudings. Meesal is gawes ' $\mathrm{n}$ vorm van ruilhandel, iemand skenk iets of doen iets vir iemand anders en verwag daarvoor iets terug, al word dié verwagting van wederkerigheid na die verre toekoms verplaas of al neem dit slegs die vorm aan van 'n sekere verhouding tussen dié partye wat daarmee tot stand kom of daardeur beïnvloed word. ${ }^{7}$ Ook wanneer daar nadruklik géén verwagting aan

5. Sien as enkele voorbeeld van die vele teoloë wat deesdae op hierdie vrae ingaan, Ellen T. Charry, God and the Art of Happiness, Grand Rapids: Wm. B. Eerdmans, 2010.

6. Karl Barth, The Christian Life. Church Dogmatics IV/4. Lecture Fragments, translated by Geoffrey W. Bromiley, Grand Rapids: Wm. B. Eerdmans, 1981, 3-46, veral 39. Sy keuse vir "aanroep van God" kom natuurlik eweneens vanuit die Heidelbergse Kategismus, soos wat hy dan ook aantoon, 43-44.

7. Marcel Mauss se invloedryke The Gift verskyn oorspronklik in 1925, sien The Gift. Forms and Functions of Exchange in Archaic Societies, London: Cohen \& West, 1966. Sedertdien word dit 'n vloedgolf van literatuur, in vele akademiese velde en interdissiplinêre gesprekke. Van die bekendste werke wat dikwels ook in teologiese gesprekke 'n rol speel sluit byvoorbeeld in John Caputo \& Michael Scanlon (eds.), God, the Gift, and Postmodernism (met onder andere bydraes van Richard Kearney en David Tracy), Bloomington: Indiana University Press, 1999; Caputo, Mark Dooley \& Scanlon (eds.), Questioning God, Bloomington: Indiana University Press, 2001; Jacques Derrida, Given Time: 1. Counterfeit Money, translated by Peggy Kamuf, Chicago: The University of Chicago Press, 1992; Derrida, The Gift of Death, translated David Willis, Chicago: Chicago University Press, 1996; Robyn Horner, Rethinking God as Gift: Marion, Derrida and the Limits of Phenomenology, New York: Fordham University Press, 2001; Jean-Luc Marion, God without Being, translated Thomas A. Carlson, Chicago: Chicago University Press, 1991; Marion, Being Given: Toward a Phenomenology of Givenness, translated Jeffrey L Kosky, Stanford: Stanford University Press, 2002; Marion, Prolegomena to Charity, translated by Stephen E. Lewis, New York: Fordham University Press, 2002; Calvin O. Schrag, God as Otherwise than Being. Toward a Semantics of the Gift, Evanston: Northwestern University Press, 2002; Alan D. Schrift (ed.), The Logic of the Gift. Toward an Ethic of Generosity, London: Routledge, 1997 (met baie gesaghebbende opstelle, insluitende een van Mauss self); Edith Wyschogrod, Jean-Joseph Goux \& Erci Boynton (eds.), The Enigma of Gift and Sacrifice, New York: Fordham University Press, 2002. 
NGTT: Oopbron - http://ngtt.journals.ac.za

gekoppel word nie, en sommige sinici sal sê juis dan, skép dit eweneens h soort verhouding, te wete een van I owe you, van afhanklikheid, van eensydige erkentlikheid, wat 'n stempel laat op die een wat ontvang het en niks mag of kan terug doen nie.

Vir ons verstaan van die evangelie is dié gedagtes uiteraard van ingrypende belang. Kan genade of vrye guns werklik gedink word? Indien dit inderdaad vrye guns is - laat dit werklik die ontvangers onveranderd, of eerder afhanklik, verskuldig en verplig? Meer nog, indien dankbaarheid verwág word, gevrá word, selfs vereis word, was dit dan werklik vrye guns, genade alleen? Kán genade gekoppel word aan enige verpligting tot dankbaarheid, en nog steeds genade wees? Meermale word Calvyn en by name die Kategismus voorgehou as klassieke voorbeelde van dié onaanvaarbare praktyk om dankbaarheid as morele motief te benut - as aansporing tot gehoorsaamheid, selfs tot gebed en aanbidding.

4. Teen die agtergrond van dié twee wyd verbreide openbare diskoerse vandag is ten minste twee baie populêre kritiese vrae aan die adres van die Kategismus gevolglik heel begryplik. Is 'n negatiewe en pessimistiese antropologie inderdaad 'n sleutelmotief in die Kategismus se verkondiging van troos? En is $\mathrm{n}$ wettiese vorm van dankbaarheid inderdaad $\mathrm{n}$ sleutelmotief in die Kategismus se motivering vir die Christelike lewe? Uitgedruk in die Latyn van die eerste vertaling van die Kategismus (reeds ook in 1563), is die miseria waarop die logika van die Kategismus berus vandag nog geloofwaardig en is die misericordia, die barmhartigheid, wat die Kategismus verkondig inderdaad vrye guns? ${ }^{8}$

\section{OOR DIE ELLENDE VAN DIE MENS}

5. Dis opvallend dat die opskrif van die eerste deel nie praat van "sonde" nie, maar van "ellende" (in Ursinus se oorspronklike Duits: von des Menschen Elend; in die eerste Latynse vertaling: hominis de miseria). Hoewel daar in die antwoord op Vraag 2 twee maal van "sonde en ellende" gepraat word (hoe ek van my "sonde en ellende verlos word"), is dit merkwaardig dat die opskrif van deel twee slegs van "ellende" praat en dat Vraag 3 direk en persoonlik vra waaruit ken ons ons ellende ken - en nié ons sonde nie.

Dalk is dit egter éérder merkwaardig dat daar vertalings is (soos die een wat in This We Believe van die NGK opgeneem is) wat die opskrif van die tweede deel aangee as "Sin and Misery" en dat dit in die spreektaal eintlik algemeen is om die driedeling van die Kategismus weer te gee met sonde-verlossing-dankbaarheid. Daar bestaan waarskynlik min twyfel oor die feit dat die populêre opvatting oor die logika van die Kategismus inderdaad is dat die eerste deel handel oor sonde, eerder as oor ellende - wat in fundamentele misverstand en verskraling van die Kategismus se eie bedoeling beteken. ${ }^{9}$

8. Vir die oorspronklike Duitse teks, in handige parallelle kolomme gepubliseer saam met die eerste Latynse vertaling en die eerste Nederlandse vertaling, sien J. N. Bakhuizen van den Brink, De Nederlandse Belijdenisgeschriften in Authentieke Teksten met Inleiding en Tekstvegelijkingen, Amsterdam: Uitgeverij Ton Bolland, 1976, 149-224, en vir agtergrond op die tekste en vertalings, 29-40. Eweneens vir 'n weergawe van die oorspronklike Duits met gedokumenteerde kommentaar op die teks, sien Wilhelm H. Neuser, "Heidelberger Katechismus von 1563," in die reeks Reformierte Bekenntnisschriften, Band 2/2, 1562-1569, Hrsg. Andreas Mühling \& Peter Opitz, Neukirchen: Neukirchener Verlag, 2009, 167-212. Vir 'n nuwe vertaling in hedendaagse Duits, sien Heidelberger Katechismus. Revidierte Ausgabe 1997, 4. Auflage 2010, hrsg. von der Evangelisch-reformierten Kirche, von der Lippischen Landeskirche und vom Reformierten Bund, Neukirchen: Neukirchen-Vluyn, 2010.

9. Die formulering, die "eie bedoeling" van die Kategismus is uiteraard 'n metafoor wat misverstand kan bevorder. Die Kategismus self het geen eie bedoeling nie en dis boonop onmoontlik om die spesifieke 
6. "Sonde en ellende" beteken óók nie - soos wat vele dit opneem - dieselfde as "ellendig" sondig, asof ellende eintlik $n$ byvoeglike naamwoord of bywoord is wat sonde en sondig net verder versterk nie, of selfs $\mathrm{n}$ oortreffende trap van sondig nie, inteendeel. Ook oor die Kategismus se verstaan van sonde - en daarmee van die blywende noodsaak en relevansie van skuld, vergiffenis, regverdiging en vryspraak - sou dieper nagedink en verder gepraat kon word, want ook die kritiek op sonde- en skuld-taal is nie so oortuigend as wat meermale geglo word nie. Sonde word egter sélf ook só misverstaan en misbruik dat die Kategismus se eie bedoelings daarmee - en gevolglik die moontlike relevansie vandag - nie genoegsaam aandag kry nie, maar dit is ' $\mathrm{n}$ tema vir' $\mathrm{n}$ ander dag. Selfs afgesien daarvan, egter, is dit eweneens nodig om die Kategismus se verstaan van ellende van nader te bekyk, ten einde te kan oordeel of dié lewensgevoel vandag nog mense kan aanspreek, of nie.

7. Menslike ellende, sou $\mathrm{n}$ mens kon begin, is volgens die Kategismus meer toestand as handeling, meer iets wat ons is as wat ons doen, meer Sein as $A k t$, of in ander terminologie, dis meer objektief as subjektief, dit het meer te make met wat en wie ons is en wat ons ondergaan, oorkom en aan uitgelewer is as met wat ons ervaar, belewe en voel. Ellende is wat van ons geld, ongeag óf en hóé ons dit gewaar word, of nie. Met vele uitdrukkings beskryf die Kategismus op vele plekke dié toestand waarin ons onsself bevind en waaruit ons bevryding benodig, ongeag of ons so voel, of nie.

8. Ons ellende is daarom iets waaroor ons bejammer eerder as van beskuldig kan word. Dis ons nood, ons magteloosheid, ons uitgelewerdheid. Dit het te make met liggaam en siel. Dit het te make met lewe en dood. Dit het ten diepste te make met die vraag aan wie of wat ons behoort, aan welke mag en magte ons uitgelewer is.

9. Ons ellende is gevolglik nié primêr empiries waar te neem en fenomenologies te beskrywe nie, wat beteken dat ons ellende nié geken word op grond van $\mathrm{n}$ pessimistiese narratief oor mens-wees, die lewe, die samelewing en die tydsgees nie. Vir die troos wat die Kategismus wil verkondig is dié insig van uiterste belang, daarom word dit so nadruklik deur die Kategismus self gevra en beantwoord. Die menslike nood en behoefte aan verlossing hang dus nie af van die

bedoelings van die skrywers na te gaan. Die Kategismus het ontstaan in 'n historiese, sosiale, politieke en kerklike maalkolk waarin vele faktore, kragte, akteurs en motiewe 'n rol gespeel het. Daar was selfs 'n span van medewerkers, alhoewel baie onlangse navorsing oortuigend aantoon dat dit grootliks die werk van Ursinus was, meer as wat voorheen besef is, en dat die rol van Olevianus kleiner was en ook van 'n ander aard, te wete om die ontvangs van die Kategismus agterna te bevorder. Dis natuurlik egter eweneens onmoontlik om Ursinus se bedoeling volledig na te vors, asof hy slegs 'n enkele bedoeling sou gehad het. By die uitleg - en dit sal altyd 'n onderlinge konflik van interpretasie moet bly - moet die historiese faktore dus allereers in ag geneem word, die Kategismus moet gelees word as 'n dokument van sy eie ontstaanstyd. Daarvoor is studies nuttig soos Walter Henns, Der Heidelberger Katechismus im konfessionspolitischen Kräftespiel seiner Frühzeit, Zürich: Theologischer Verlag, 1983, asook verskeie bydraes in die uitstekende resente bundel van Heimbucher et al, Zugänge (sien voetnoot 2). Daarby behoort die teologiese vorming en eie oortuigings van Ursinus ernstig geneem te word, waarby werke soos Der Heidelberger Katechismus und vier verwandte Katechismen, Darmstadt: Wissenschaftliche Buchgesellschaft, 1969 (oorspronklik Leipzig, 1907), met 'n inleiding van A. Lang, steeds waardevol bly, omdat ' $n$ mens die Kategismus met Ursinus se eie vroeëre pogings kan vergelyk. Uiteindelik help die vele beskikbare studies, insluitende bydraes wat tans verskyn, dat 'n mens die struktuur, aksente, oorgange en temas van die dokument tog beter kan verstaan - en dit is al wat bedoel sou kon word met "eie bedoeling", in kritiese afstand dan van vorme van uitleg wat dalk in die resepsie-geskiedenis invloedryk geword het maar wat nie reg laat geskied aan wat ons vandag van die dokument self kan weet en verstaan nie. 
NGTT: Oopbron - http://ngtt.journals.ac.za

beskrywing van meer positiewe lewensgevoelens in meer optimistiese tye en meer negatiewe lewensgevoelens in meer pessimistiese tye nie. Daar kom (vir sommige) tye van voorspoed en vooruitgang en daar kom (vir ander) tye van teenspoed en dreigende apokaliptiese ondergang, maar die menslike ellende waarvan die Kategismus praat word nie daardeur minder of meer nie. Trouens, tye van optimisme en voorspoed kan tye van diepe nood en ellende wees - sonder dat ons dit subjektief beleef en aanvoel - en tye van pessimisme en swaarkry kan tye van bewaring en bevryding wees - sonder dat ons dit subjektief so beleef en aanvoel.

10. Daar is - interessant genoeg - vandag wel vele narratiewe van ellende in omloop, en meermale van diégene van wie h mens dit nie sou verwag nie, omdat hulle nié noodwendig die beoordeling van die menslike kondisie van die Kategismus deel nie. Dis maklik om lyste van bekende figure en hulle invloedryke werke op te noem as voorbeelde van dié litanieë van die nood van ons tyd.

'n Mens dink byvoorbeeld aan die Britse regsgeleerde en etikus, Jonathan Glover, se Humanity. A Moral History of the Twentieth Century (2001), wat 'n aangrypende, diep beskuldigende weergawe is van die onmenslikheid en die gruwel van die tyd waarin ons lewe en van die ménse van ons tyd..$^{10}$ Daar is Peter Watson se fassinerende $A$ Terrible Beauty, waarin hy die wonderbare rol van tallose wetenskaplike ontwikkelings op ons daaglikse bestaan beskrywe, maar tog deurentyd bewus van die groter verhaal en atmosfeer van verskrikking. ${ }^{11}$ Daar is die sielkundige Daniel Haybron se ontmaskerende studie oor die kultuur van happiness, The Pursuit of Unhappiness. The Elusive Psychology of Well-Being, waarin hy toon hoe juis die ideale en drome wat ons najaag só onbereikbaar is dat hulle nie anders kán as om vir ewig gevoelens van onvervuldheid, afguns, frustrasie en onbehae by ons te skep nie. ${ }^{12}$ 'n Mens dink aan die populêre kultuur-filosoof Alain de Botton se meesleurende Status Anxiety, waarin hy vertel hoe die groot storie van die Christelike geloof, soos wat dit ook in die Heidelbergse Kategismus neerslag sou vind, in ons tyd vervang is met $\mathrm{n}$ nuwe groot storie, maar een waarvan stres, mededinging, afguns en sosiale vrees die bittere alledaagse gevolge is. ${ }^{13} \mathrm{n}$ Mens onthou die New Yorkse filosoof Simon Critchley se snydende Infinitely Demanding, waarin hy argumenteer dat nihilisme, leegheid, sinloosheid dié uitdaging, ja, bedreiging van ons tyd is, omdat mense niks meer het om waarlik voor te lewe, geen roeping, geen aanspraak, geen verbintenis van werklike waarde nie. ${ }^{14}$ Daar is Jan Philip Reemtsma, die invloedryke Hamburgse sosiaal-wetenskaplike, se ontstellende en soms siniese Vertrauen und Gewalt, waarin hy van vele kante uitspel hoe die moderne tyd en die moderne lewe integraal verweef is met, ja, berus op die alomteenwoordigheid van geweld en dreiging van geweld. ${ }^{15}$ Daar is die ontboesemende erkenning van die gevierde Duitse skrywer Martin Walser dat hy, dat álle mense, regverdiging nodig het, maar dat die oppervlakkige kultuur van ons tyd,

10. Jonathan Glover, Humanity. A Moral History of the Twentieth Century, New Haven: Yale University

Press, 2001.

11. Peter Watson, A Terrible Beauty. The People and Ideas that Shaped the Modern Mind. A History,

London: Phoenix Press, 2002.

12. Daniel M. Haybron, The Pursuit of Unhappiness. The Elusive Psychology of Well-Being, Oxford:

Oxford University Press, 2008.

13. Alain de Botton, Status Anxiety, London: Penguin, 2005.

14. Simon Critchley, Infinitely Demanding, New York: Verso, 2007.

15. Jan Philip Reemtsma, Vertrauen und Gewalt. Versuch über eine besondere Konstellation der Moderne, Hamburg: Hamburger Institut für Sozialforschung, 2008. 
met literatuur, kuns, media, politiek alles daarmee saam, alles wat moontlik is doen om dié diepe nood te verdryf en te ontken en te probeer vervang deur self-regverdiging en beterweterigheid - waarvan net ' $\mathrm{n}$ radikale religie ons kan bevry, soos by Paulus, Augustinus, Luther, Calvyn, en Barth, sê hy, in sy opspraakwekkende Über Rechtfertigung, eine Versuchung. ${ }^{16}$ Daar is ingrypende besinning oor lyding in ons tyd, soos van die Franse psigoanalitikus Julie Kristeva, byvoorbeeld in haar This Incredible Need to Believe. ${ }^{17}$ Daar is 'n oplewing aan studies oor die bose in ons tyd, oor kwaad en boosheid, soos in Terry Eagleton se On Evil. ${ }^{18}$ Daar is selfs die apokaliptiese denkbeelde van vele hedendaagse filosowe, waar onder Slavoj Zizek, soos in sy Living in the End Times. ${ }^{19}$

Al hierdie werke is van vandág, en óór vandag, en nie van skrywers wat juis bedoel om as gelowiges te skryf nie. Indien n mens teoloë sou byvoeg word die lys nóg langer, as 'n mens dink aan Cornelius Plantinga se Not the way it's Supposed to Be, aan Christof Gestrich se beskrywing, in Die Wiederkehr des Glanzes in der Welt, van 'n lewe "when things no longer have any splendor" of aan Serene Jones se Trauma and Grace, oor wat sy 'n gebroke wêreld noem, ruptured, vol geweld, trauma en rou. ${ }^{20}$

En as 'n mens van die beskrywings onthou wat verder agter dié tekeninge lê, dink 'n mens aan Alasdair Maclntyre se wêreld After Virtue, waarvolgens ons tyd ons morele sensibiliteit en woordeskat verloor het, ${ }^{21}$ en nog verder terug aan Hannah Arendt oor the banality of evil, die alledaagsheid, die gewoonheid, die bekéndheid van die bose, ${ }^{22}$ aan Walter Benjamin se bittere beskrywing van die katastrofe wat ons vooruitgang noem ${ }^{23}$ - of nóg verder terug aan Emile Durkheim se analises van anomie, van die belewenis van mense dat hulle nie tuis is in hulle eie gemeenskap en samelewing nie, nie hier hoort of pas

16. Martin Walser, Über Rechtfertigung, eine Versuchung, Hamburg: Rowohlt, 2012.

17. Julia Kristeva, This Incredible Need to Believe, translated Beverley Bie Brahic, New York: Columbia University Press, 2009.

18. Terry Eagleton, On Evil, New Haven: Yale University Press, 2010.

19. Slavoj Zizek, Living in the End Times, London: Verso, 2010.

20. Cornelius Plantinga, Not the way it's Supposed to Be, Grand Rapids: Wm. B. Eerdmans, 1996; Christof Gestrich, Die Wiederkehr des Glanzes in der Welt, Tübingen: J. C. B. Mohr (Paul Siebeck), 1996; Serene Jones, Trauma and Grace. Theology in a Ruptured World, Westminster John Knox, 2009.

21. Alasdair MacIntyre, After Virtue. A Study in Moral Theory, Notre Dame: University of Notre Dame Press, 1981.

22. Hannah Arendt gebruik die term "banality of evil" in haar beskrywing van die verhoor van Adolf Eichmann, in haar opspraakwekkende boek Eichmann in Jerusalem. A Report on the Banality of Evil, 1963. In 'n sin word haar gebruik van dié term juis die fokus van die skerp kritiek wat sy veral vanuit Joode kringe ontvang, omdat hulle verwagting was dat sy hom as veel erger en meer grusaam moes uitbeeld as wat sy doen.

23. Walter Benjamin gebruik dié formulering in sy aangrypende "Theses on the Philosophy of History," die laaste werk wat hy ooit geskryf het, en wat eers na sy dood deur vriende gepubliseer is. Vir die teks van die teses, sien Benjamin, Illuminations, New York: Schocken Books, 1977, 253-264. Vir 'n inleiding tot sy lewe en werk, sien die bundel opstelle onder redaksie van Gary Smith, On Walter Benjamin, Critical Essays and Recollections, Cambridge: MIT Press, 1991 en vir bondige inleidings tot sy afsonderlike werke, sien Uwe Steiner, Walter Benjamin. An Introduction to his Work and Thought, Chicago: University of Chicago Press, 2010. 
NGTT: Oopbron - http://ngtt.journals.ac.za

nie, ${ }^{24}$ aan Kierkegaard se sickness unto deat $h^{25}$ en aan Hegel se vervreemding, alienation. ${ }^{26}$

Elkeen van hierdie beskrywings van die conditio humana vind vandag nog wye en invloedryke nawerkinge - by vele voorste kultuur-kritici van ons dag.

Die punt is dat hierdie nié die denkpatroon van die Kategismus is nie. Die Kategismus het hierdie soort empiriese argument nie nodig nie. Dit mag vir predikers wel verleidelik klink om sulke gesaghebbende stemme te hê wat wél klink na pessimistiese antropologiese narratiewe, en dit mag dalk 'n sekere kommunikatiewe en selfs retoriese waarde hê, maar uiteindelik is die Kategismus nie geïnteresseerd in ' $\mathrm{n}$ is/is-nie debat oor hoe goed of hoe sleg mense, die tydsgees en die samelewing is nie. Die Kategismus vra nadruklik, waaruit ken ons ons ellende?, en antwoord: uit die wet van God (Vraag 3) - nié deur die uitkyk by die venster (Ernst Bloch), die luister na nuusberigte, die lees van Glover, Walser of Zizek nie, hoe aangrypend en ontstellend al dié verhale ook al mag wees.

Dié wet hoor ons in die samevatting van die wet wat Jesus volgens die Evangelies gegee het (Vraag 4). Ons is goed en na Gods eie beeld geskape, in ware geregtigheid en heiligheid (Vraag 6), maar ons is van hierdie gawes beroof (Vraag 9) en daarom, tensy ons weer deur Gods Gees opnuut gebore sou word (Vraag 8) is ons nié self in staat (Vraag 5) om God en ons naaste lief te hê (Vraag 4) soos wat ons eintlik as mense gemaak en geroepe is om te wees nie. Dit is ons ellende - wat ons sien in die spieël van die evangelie, van wie ons eintlik is en kan wees en moes wees. Ons is nie onsself nie, ons is vervreem van onsself. Ons weet dit, nie omdat ons dit waarneem of voel nie, maar omdat dit vir ons gesê word en ons dit hóór.

11. Dis daarom nie verrassend dat die Kategismus die woord ellende, Elend, gebruik om ons toestand, ons miseria, mee te beskryf nie. Die stam van ellende is dieselfde as dié van alien en alienation, van vreemd, vreemdeling, vervreemd wees, in n vreemde wêreld, ontuis. Ons ellende is dat ons aan onsself behoort - en daarmee aan allerhande ander magte. ${ }^{27}$ Dwarsdeur die Kategismus word dié magte aan wie ons behoort op verskillende maniere benoem. ${ }^{28}$ Ons troos is dat ons aan Jesus Christus behoort, bevry van hierdie magte én van onsself.

12. In die lig hiervan is dit bevreemdend dat ons die logika van die Kategismus so maklik kon herlei tot vergiffenis van sonde alleen - en dié dan boonop kon uitlê op $\mathrm{n}$ individualistiese en

24. Die Franse sosioloog Emile Durkheim, die grondlegger van die sosiologie as akademiese dissipline, het die konsep van anomie bekend gemaak as beskrywing van 'n lewensgevoel, karakteristiek van moderne samelewings, dat mense ontuis is; vir 'n bespreking van die breër tema, sien byvoorbeeld my "Gemeenskap wat kan standhou? - Nagedink oor vorme van sáám-leef in die wêreld vandag," Geloof en Openbare lewe. Versamelde Opstelle 2, Nico N. Koopman (red), Stellenbosch: Sun Press, 2008, 35-66.

25. Soren Kierkegaard is bekend vir sy beskrywing van die menslike sickness unto death, ook die titel van een van sy werke, uit 1849, onder die skuilnaam Anti-Climacus. Hy bedoel dit as 'n Christelike analise van sonde, wat hy as wanhoop tipeer, despair, deur drie verskillende gestaltes van eksistensiële wanhoop te beskryf.

26. Veral sedert Hegel word die term vervreemding, alienation, deur verskillende denktradisies gebruik om die menslike toestand mee aan te dui, waaronder Marx en sy volgelinge, wat dit egter anders gebruik as Hegel self.

27. Sien Eberhard Busch, Drawn to Freedom. Christian Faith Today in Conversation with the Heidelberg Catechism, Grand Rapids: Wm. B. Eerdmans, 2010, 63-91.

28. Byvoorbeeld alle heerskappy van die duiwel (Antwoord 1), ons verdorwe natuur (Antwoord 6), die aanhitsing van die duiwel (Antwoord 9), alles wat met ons gebeur (Antwoord 27), alle heerskappy van die duiwel (Antwoord 34), alle vyande (Antwoord 51), al sy en my vyande (Antwoord 52), die werke van die duiwel, magte, kwaadwillige planne (Antwoord 123), ons doodsvyande, die duiwel, die wêreld en ons sondige natuur (Antwoord 127). 
moralistiese wyse. Barth se verbasing geld ook hier. Wanneer hy in sy Kirchliche Dogmatik die Christologie bedink in sy versoeningsleer en hy by Jesus se wonderbare wonderdade in die Evangelies kom, merk hy op:

"(W)e may well ask with amazement how it was that the Reformation, and (apart from a few exceptions) the whole of earlier and especially more recent Protestantism as it followed both Luther and Calvin, could overlook this dimension of the Gospel which is so clearly attested in the New Testament - its power as a message of mercifully omnipotent and unconditionally complete liberation from $\varphi \theta 0 \rho a$, death and wrong as the power of evil. How could Protestantism as a whole, only too faithful to Augustine, the 'father of the West,' orientate itself in a way which is so one-sidedly anthropological (by the problem of repentance instead of by its presupposition - the kingdom of God)?

In other words, how could it become such a moralistic affair - so dull, so indifferent to the question of humanity itself, and therefore so lacking in joy? How could it possibly overlook the fact that it was depriving even its specific doctrine if justification and sanctification of so radiant a basis and confirmation by not looking very differently at the character of the self-revelation of God in the Son of Man as it emerges in the miracles of Jesus, in these works of God; by not considering the freedom of the grace which appeared in Him?And ... there is nothing much to be learned in this respect from Western Catholicism ... From the Reformers we can at least know what free grace might be, and therefore learn, perhaps, to recognise its radicalism as revealed in the miracles of Jesus." ${ }^{29}$

Kortom, hy verbaas hom dat Protestantisme wel die vrye aard van Gods guns gesien het, maar nie die reikwydte en radikaliteit daarvan nie. Hulle het nie gesien dat genade nie slegs met sonde te make het nie, maar ook met die mens, met dié menslike vraag, naamlik die vraag na lyding onder die geweld van die magte van kwaad en dood. Protestantisme het toegelaat dat hulle eie vooroordeel, hulle particular bias, hulle verhinder om te sien wat so oop en bloot is in die evangelie. Hulle het self toegelaat dat hulle a moralistic affair word en daarmee - so indifferent to the question of humanity itself. Sonde het feitlik iets verdiensteliks geword, iets wat mense nodig het, omdat dit ons waardig maak vir die verlossing.

"To whom does Jesus turn in the miracles?, vra Barth, en antwoord self"The answer is obvious. It is the person with whom things are going badly; who is needy and frightened and harassed ... The picture brought before us is that of suffering ... We may turn away from this aspect of human existence. We may close our eyes to it. We may argue that human life as a whole is not really like a great hospital. But apart from this aspect the miracles of Jesus cannot be brought into proper focus and genuinely seen and understood. For human life as it emerges in this activity of Jesus is really like a great hospital whose many departments in some way enfold us all ... His action is always in response to human misery... He finds and sees people in the shadow of death. His miraculous action is to bring them out of this shadow, to free them from this prison, to unburden them, to release them. They can be people again - whole people in the most elemental sense ...

29. Sien Karl Barth, Church Dogmatics IV/2, 154-264, veral 233. Vir 'n bespreking van die breër samehang by Barth, sien my "Paradigms of Radical Grace," in On Reading Karl Barth in South Africa, Charles Villa-Vicencio (ed.), Grand Rapids: Wm. B. Eerdmans, 1988, 17-44, ook opgeneem in my Essays on Being Reformed. Collected Essays 3, Robert Vosloo (ed.), Stellenbosch: Sun Press, 2009, 275-292. 
NGTT: Oopbron - http://ngtt.journals.ac.za

The fact that God takes people seriously in this direct divine way finds concrete realisation when Jesus' proclamation of his kingdom, his coup d'état in the miracles, takes the form of this direct comforting of the sad, this free liberation of the poor, these benefits which come so unconditionally to people; when in this form it consists quite simply in the fact that oppressed and therefore anxious people can breathe and live again, can again be people...

It is in this that God is glorious, making known God's will, and in God's will God's nature... The God who is operative and revealed in the acts of Jesus self-evidently places Godself at the side of people in this respect - that which causes suffering to people is also above all painful and alien and antithetical to Godself ... God does not will that which troubles and torments and disturbs and destroys people... The sorrow which openly or secretly fills the heart of people is primarily in the heart of God. The shame which comes on people is primarily a violation of God's own glory. The enemy who does not let people breathe and live, harassing them with fear and pain, is primarily God's enemy ...

The activity of Jesus, and revealed in it Godself and God's kingdom, are a defiance of the power of destruction which enslaves people, of $\varphi \theta 0 \rho a$ in all its forms. They are not a neutral force or omnipotence, but the omnipotence of mercy - not quiet and passive mercy, but a mercy which is active, and therefore hostile to that power on behalf of poor people ... It is on the side of suffering people that God, Godself, sets Godself. It is to the help of the sufferer that God comes." ${ }^{\prime 30}$

Die wondere help ons sien dat Gods genade radikaal en onvoorwaardelik gerig is op mense in ons ellende, nie net as sondaars nie, maar ook as skepsele. In die woorde van Jaap Durand, hulle dien as paradigmas van Gods genade, ${ }^{31}$ van Gods barmhartige ontferming, Gods misericordia, van die troos van Gods radikale en omvattende vrye guns. ${ }^{32}$

13. Dit is hierdie omvattende nood, hierdie ellende, hierdie behoort-aan-die-magte en hierdie-uitgelewer-wees-aan-onsself wat die Kategismus in die oog het as dit praat van ons misery, van ons alienation, van ons vervreemding. Dit is hierdie radikale vrye guns van Gods barmhartigheid en genade wat die Kategismus verkondig as enigste troos, vir liggaam en siel, in lewe en sterwe. Juis om dié rede staan alles egter op die spel indien die tweede aanklag gelyk sou hê, te wete dat die Kategismus se klem op dankbaarheid beteken dat die genade juis nie genade is nie en die vrye guns nié vry nie.

30. Barth, $C D I V / 2,233$ e.v.

31. J. J. F. Durand, Die Lewende God, Pretoria: NGKB, tweede uitgawe 1986, 109-110.

32. Die term misericordia kom meermale in die 1563 Latynse vertaling voor, byvoorbeeld Vraag en

Antwoord 10: is God dan nie misericors nie? met die antwoord God is sekerlik barmhartig, est ille quidem misericors. By die sleutelvraag en -antwoord 21, oor wat 'n ware geloof is, word gesê dat al die gawes ons uit louter genade, ex Dei misericordia, geskenk word. In Antwoord 122 word misericordia ingesluit in die lang ry hoedanighede van God waarom ons in die eerste bede van die Onse Vader bid dat ons dit sal ken en prys vanuit Gods werke in die skepping. Eindelik, in die belangrike Vraag 86 waarom deel drie oor die dankbaarheid aanvang, word sowel miseria as misericordia in één asem gebruik. Dis merkwaardig dat die Latynse vertaling reeds hier "sonde" invoeg by die oorspronklike Duitse teks wat net "ellende" het (ausz unserm elend; ab omnibus peccatis et miseriis) en ewe merkwaardig dat die Latyn dan die Duitse "genade" (ausz gnaden) met "Gods barmhartigheid" weergee (sola Dei misericordia). 


\section{OOR DANK VIR GENADE}

14. Die verwyt dat dankbaarheid nié kan funksioneer as motivering vir die Christelike lewe en dus vir die etiek nie kom van vele kante. Meesal word dié beskuldigings aan die adres van Calvyn gerig, wat met sy logika van Grace and Gratitude - die titel van Brian Gerrish se gesaghebbende Calvyn-studie ${ }^{33}$ - dankbaarheid tot $\mathrm{n}$ motivering verhef het wat juis die genade sy genadekarakter ontneem, lui die kritiek. As dankbaarheid verwag, erger nog, vereis word, was dit van die begin af geen ware genade gewees nie. In sommige kringe word selfs verder gegaan en word die vraag gestel of egte genade hoegenaamd denkbaar en voorstelbaar is, en weer eens is Calvyn dikwels die hoof-aangeklaagde - soos by verskeie verteenwoordigers van die Radikale Ortodoksie, soos John Milbank, ${ }^{34}$ maar ook by teoloë soos Stephen Webb en Graham Ward en ander. ${ }^{35}$ In die latere Calvinisme sou dié misplaaste motief dan rype neerslag gevind het in verregaande wettisisme, moralisme, werkheiligheid en onvryheid, lui die klag meesal verder.

15. Dikwels word dié beskuldiginge egter ook uitdruklik teen die Heidelbergse Kategismus gerig, soms al vir sy eie (doelbewuste) strekking en logika, soms vir sy (dalk onbedoelde?) bydrae tot misverstande en misbruik in die tradisie sedertdien.

Só skryf Bernd Wannenwetsch byvoorbeeld: "Darum hat der Heidelberger Katechismus durchaus zu einer problematischen Traditionsbildung beigetragen, indem er die Dankbarkeit als erste Antwort auf die Frage nach dem moralischen Sollen einführt: 'Warum sollen wir gute Werke tun?' (86. Frage). Zwar ist die Abwehr des verdienstlichen Denkens im Zusammenhang der Werke als primäres Motiv anzuerkennen. Und doch kommt im Gedanken der Gründung der christlichen Ethik auf die Dankbarkeit ein Zungenschlag ins Spiel, der - ungewollt - das vorbereitet, was dann in Kants radikaler Gesinnungsethik in seiner reinen Form zutage treten sollte: die Funktionalisierung des gottesdienstlichen Geschehens ... Kinder äussern spontanen Dank. 'Dankbarkeit' hingegen verrät eine knechtische Gesinnung. Sie gehört zur 'Sklavenmoral', zum Habitus derer, die sich ... in Dankbarkeit üben müssen, weil sie keinen freien Zugang ... haben." ${ }^{\prime 36}$

16. Daar kan min twyfel bestaan dat die latere Calvinisme in vele gestaltes $\mathrm{h}$ spiritualiteit beoefen het - en dalk steeds beoefen - wat inderdaad as wettisisme en moralisme beskryf moet word nie. Daar kan ook min twyfel oor bestaan dat $\mathrm{n}$ sekere manier van omgang met die driedeling van die Kategismus, gereduseer tot $\mathrm{n}$ formule-agtige skema van sonde-verlossing-

33. Brian Gerrish, Grace and Gratitude, The Eucharistic Theology of John Calvin, Eugene: Wipf \& Stock, 1993.

34. Verskeie van John Milbank se opstelle behandel direk die gereformeerde logika, waar onder "Can a Gift be Given? Prolegomena to a Future Trinitarian Metaphysic," in Gregory L. Jones \& Stephen E. Fowl (eds.), Rethinking Metaphysics, London: Blackwell, 1996, 119-161; "The Ethics of Self-Sacrifice," First Things, March 1999, 33-38; en "The Soul of Reciprocity" in twee aflewerings, in Modern Theology, 17/3 July 2001 en 17/4 October 2001; sien ook Milbank, Being Reconciled: Ontology and Pardon, London: Routledge, 2003.

35. Stephen Webb, The Gifting God: A Trinitarian Ethics of Excess, Oxford: Oxford University Press, 1996; Graham Ward, Cities of God, London: Routledge, 2000; Miroslav Volf, Free of Charge. Giving and Forgiving in a Culture Stripped of Grace, Grand Rapids: Zondervan, 2005.

36. Bernd Wannenwetsch, Gottesdienst als Lebensform - Ethik für Christenbürger, Stuttgart: Verlag W. Kohlhammer, 1997, 48-52; sien my bespreking in "Politieke erdiens? Vrae oor liturgie as lewensvorm," Geloof en Openbare Lewe. Versamelde Opstelle 2, Nico N. Koopman (red), Stellenbosch: Sun Press, 2008, 175-190. 
NGTT: Oopbron - http://ngtt.journals.ac.za

dankbaarheid, dié spiritualiteit grootliks help bevorder het. Maar was dit die bedoeling van die Kategismus self? Of eerder, is dit al manier om die logika van die Kategismus te verstaan?

Skerp gestel, is die derde deel van die Kategismus 'n reaksie op die troos, met die troos dan verstaan as inhoud van die middelste deel? Of is die derde deel self déél van die troos? Is dankbaarheid die eis tot menslike reaksie óp die vrye guns, of is dankbaarheid self déél van die werking van die vrye guns? Is dankbaarheid die gepaste handeling van menslike kant in die lig van die voorafgaande genadige Goddelike handeling - in die gees van dit het Ek alles vir jou gedoen, wat doen jy nou vir My? Of is dankbaarheid die integrale en spontane werking van die Goddelike handeling self? Indien die vraag wat op die spel is só gestel word, word die Kategismus se antwoord eintlik merkwaardig duidelik. Of die uitlegtradisie in prediking, lering, kategese en toepassing getrou gebly het aan dié antwoord is uiteraard $\mathrm{n}$ volgende vraag.

17. Die Kategismus se eie bedoeling blyk al glashelder - en waarskynlik verrassend, vir vele - uit die bekende Antwoord 1. Die probleem is waarskynlik dat die tradisie meesal halfpad opgehou het by die lees van hierdie antwoord. Wat is jou enigste troos in lewe en sterwe, vra die Kategismus, en antwoord self:

Dat ek met liggaam en siel in lewe en in sterwe nie aan myself nie, maar aan my getroue Verlosser, Jesus Christus behoort. Hy het met sy kosbare bloed vir al my sondes ten volle betaal en my uit alle heerskappy van die duiwel verlos. Hy bewaar my op so 'n wyse dat sonder die wil van my hemelse Vader geen haar van my kop kan val nie. Alles moet inderdaad tot my saligheid dien. Daarom verseker Hy my ook deur sy Heilige Gees van die ewige lewe en maak Hy my van harte gewillig en bereid om voortaan vir Hom te lewe.

Die troos is dat ons aan nie aan onsself behoort nie, maar aan ons getroue Verlosser Jesus Christus - in lewe en sterwe, met liggaam en siel. Wat hou dié behoort alles in? Die lys met merkwaardige werkwoorde, waarin Jesus Christus se werksaamheid uitgespel word, maak dit duidelik. Hy betaal ten volle vir ons sonde, ja, en volgens baie in die uitlegtradisie hou die antwoord eintlik daar op, maar Jesus Christus verlos ons ook (uit alle bose heerskappy), Hy bewaar ons ook (die hare op ons hoof), Hy verseker ons deur sy Heilige Gees en, merkwaardig, Hy maak ons deur die Heilige Gees bereid om voortaan vir Hom te lewe, ja, "van harte gewillig en bereid" daartoe.

Dis sonder meer duidelik dat die troos volgens die Kategismus álles insluit wat hierna uitgewerk gaan word - vir seker óók deel drie. Die troos strek uit óók oor die dankbaarheid, die dankbaarheid is nié ons reaksie op die troos wat bloot daaraan voorafgaan nie. Alles is ingesluit by die troos dat ons aan Christus behoort. Christus doen álles aan ons, deur sy Heilige Gees - en wel op só 'n wyse dat ons ontdek dat ons van harte gewillig en bereid, dankbaar, gemáák word.

18. Wie die uitdrukkings volg wat in die res van die Kategismus gebruik word, sien inderdaad hiérdie logika aan die werk, só duidelik dat dit eintlik verrassend, bevreemdend, word dat die uitlegtradisie dit so dikwels kon miskyk en anders aanwend.

Die troos veronderstel dat ons "deur die Gees van God weergebore word", anders het ons geen hoop nie (Antwoord 8). Integraal deel van die ware geloof, waardeur mense gered word, is die "vaste vertroue wat die Heilige Gees deur die evangelie in ons hart werk" (Antwoord 21) - en later gaan nog uitgespel word hóé die Gees dit doen. 
Integraal deel van die inhoud van dié geloof is die derde deel van die Apostoliese Geloofsbelydenis, wat handel oor "die Heilige Gees en ons heiligmaking" (Antwoord 24). Dat Jesus die Christus is hou óók in dat Hy as Koning "ons met sy Woord en Gees regeer en ons by die verlossing wat verwerf is beskerm en bewaar" (Antwoord 31) - die uitdrukking "sy Woord en Gees" vervul 'n belangrike funksie en bundel saam hóé Jesus Christus met ons werk.

Ons word Christene genoem, omdat ons deur die geloof "lede van Christus is en daardeur deel aan sy salwing het, sodat ons sy Naam kan bely, onsself as lewende dankoffers aan Hom kan toewy, in hierdie lewe met ' $\mathrm{n}$ vrye gewete teen die sonde en die duiwel kan stry en hierna met Christus kan regeer" (Antwoord 32) - hierdie gemeenskap met Jesus Christus en hierdie déél in Hom, wat dan al hierdie ander aktiwiteite aan ons kant insluit en moontlik maak, is waarskynlik dié enkele sleutel tot die denke onderliggend aan die Kategismus.

Deel van die nut van sy kruisdood is dat deur "sy krag" ons ou mens "saam met Hom" gekruisig, gedood en begrawe word, sodat "die sonde gevolglik nie meer oor ons heers nie, maar ons onsself as dankoffers aan Hom kan toewy"(Antwoord 43). Deel van die nut van sy opstanding is dat ons nou ook "deur sy krag" tot "nuwe lewe opgewek word" (Antwoord 45). Deel van die nut van sy hemelvaart is dat Hy sy Gees na ons stuur deur wie "se krag" ons nou soek wat daar bo is (Antwoord 49). Deel van die nut van sy sit aan Gods regterhand in heerlikheid is dat van daar "regeer" word (Antwoord 50), "gawes uitgestort" word en ons "teen alle vyande beskerm en bewaar word" (Antwoord 51).

Sentraal in die geloof in die Heilige Gees is die troos dat dié Gees "ons deur' $\mathrm{n}$ ware geloof deel laat kry" aan Christus "en al sy weldade", dat die Gees ons "troos" en "ewig by ons bly" (Antwoord 53). Deel van die troos van die belydenis aangaande die kerk is dat Jesus Christus "deur sy Woord en Gees" die gemeente "vergader, beskerm en onderhou" en boonop nog dat "ons daarvan lewende lede is en ewig sal bly" (Antwoord 54). Die belydenis van die gemeenskap van die heiliges beteken dat ons "almal saam en elkeen afsonderlik as lede met die Here Christus gemeenskap het en aan al sy skatte en gawes deel het," wat inhou "dat elkeen verplig is om ons gawes gewillig en met vreugde tot nut en saligheid van die ander lede aan te wend" (Antwoord 55) - kortom, die "gawes" waarin ons deel omdat ons deel van Christus is behoort ons ook met ander te deel, en wel "gewillig en met vreugde". Deel van die troos van die vergiffenis van sonde is dat God op grond van Christus "ook aan my sondige aard waarteen ek my lewe lank moet stry nooit meer wil dink nie" (Antwoord 56).

As die Kategismus uiteindelik opsom wat dié geloof ons baat, word die bekende woorde van 1 Kor 1:30 twee maal gebruik, om duidelik te maak dat die "heiligheid" van Christus ons ook "geskenk" word en wel "uit louter genade" en "sonder enige verdienste aan ons kant", en net om totaal seker te maak dat dit nie misverstaan word nie, word bygevoeg dit word ons "toegereken" asof "ons self al die gehoorsaamheid volbring het wat Christus vir ons volbring het" (Antwoorde 60 en 61; sien ook reeds baie uitdruklik Antwoord 18). Ons goeie werke verdien absoluut niks nie, omdat alle beloning "uit genade" gegee word (Antwoord 63).

Waar kom hierdie geloof vandaan? Nou maak die Kategismus seker dat daar geen twyfel kan wees nie, alles kom van Christus deur sy Woord en Gees. Die Heilige Gees 
NGTT: Oopbron - http://ngtt.journals.ac.za

werk die geloof in ons harte deur die verkondiging en versterk dit deur die gebruik van die sakramente (Antwoord 65) - en dis nodig om te sien, nie deur die (elemente van) die sakramente nie, maar deur die gebruik daarvan, wat inderdaad ons handeling is, nes die geloof óns kennis en vertroue is, maar deur die Heilige Gees gebruik word. Deur die gebruik van die sakramente (Antwoord 66) word ons beter laat verstaan, beseël (Antwoord 66), gewys, geleer, verseker, (Antwoord 67, 69, 71, 73), beloof, gewas (Antwoord 70), trouens, "vernuwe en as lede van Christus geheilig om al hoe meer die ou mens af te sterwe en godvresend en onbesproke te lewe" (Antwoord 70).

Die gemeenskap met Christus wat in die nagmaal versterk word, het veral duidelike implikasies vir ons lewe. Om Christus se liggaam te eet en sy bloed te drink "beteken boonop om deur die Heilige Gees, wat tegelyk in Christus en in ons woon, al hoe meer so met sy geseënde liggaam verenig te word dat ons vlees van sy vlees en been van sy gebeente is, al is Christus nou in die hemel en ons op die aarde. Dit wil sê dat ons deur een Gees - soos die ledemate van die liggaam deur een siel - ewig lewe en geregeer word" (Antwoord 76). Die gebruik van die nagmaal is gevolglik vir dié wat "ook begeer om hulle geloof hoe langer hoe meer te versterk en hulle lewe te verbeter" (Antwoord 81).

Dáármee breek die derde deel "Oor die Dankbaarheid" aan (Ursinus: "Von der Dankbarkeit"; 1563-Latyn: "De Gratitudine," dus nié oorspronklik "Die dankbaarheid wat ons aan God vir die verlossing verskuldig is," soos wat die huidige Afrikaanse vertaling lui, na aanleiding van die oudste Nederlandse vertaling nie). ${ }^{37}$

Teen dié tyd kan daar egter eintlik geen twyfel meer wees oor die Kategismus se eie bedoeling nie. Die dankbaarheid is nie $\mathrm{n}$ los, derde deel wat volg as menslike reaksie op die troos van die eerste twee dele nie, inteendeel. Die dankbaarheid is integraal déél van die troos, dis sélf die vrug van die werk van Jesus Christus deur sy Woord en Gees, dis die spontane en onmisbare déél van die geloof wat aan ons geskenk word en in ons gewerk word deur die Gees. Daar is geen manier waarop die Kategismus nou sal wil oorgaan in 'n wettiese logika van werkheiligheid of verdienstelikheid nie. Trouens, in Vraag 64 het die Kategismus self reeds uitdruklik hierop ingegaan.

Vraag 64: Maar maak hierdie leer nie mense onverskillig en roekeloos nie?

Antwoord: Nee, want dis onmoontlik dat mense wat deur'n ware geloof in Christus ingeplant is nie vrugte van dankbaarheid sal voortbring nie.

Feitlik elke uitdrukking hier is swanger aan betekenis, binne die logika van die Kategismus. Die "ware geloof" (deur die Gees gegee én versterk) "plant" ons "in Christus" in, gee ons déél aan Christus, sodat ons aan Hom behóórt, en in dié geméénskap met Christus volg die dankbaarheid "soos vrug" en kan dit onmoontlik anders wees. Dit álles is deel van die inhoud van ons troos.

Kortom, die "onmoontlik" van die Kategismus is baie duidelik nié die onmoontlik van "dis tog onmoontlik dat mense só $n$ gawe ontvang en dan nie dankbaarheid daarvoor toon nie, dit sou darem net te skandalig vir woorde wees." Dis nié die onmoontlik van n ruiltransaksie wat een

37. Vir ' $n$ uitdruklike bespreking van die plek van die Christelike lewe in die Heidelbergse Kategismus deur 'n vooraanstaande etikus, sien Allen Verhey, Living the Heidelberg: The Heidelberg Catechism and the Moral Life, Faith Alive, 1986. 
party in morele skuld laat by 'n ander nie. Die"onmoontlik" van die Kategismus is die onmoontlik van "dis tog ondenkbaar dat mense wat aan Christus behoort, wat in Christus is, wat deel is van Christus, wat deel het aan sy eie salwing deur die Gees, wat in gemeenskap leef met Christus, wat daarom déél het aan al die genadige werkinge van Christus deur sy Woord en Gees, wat deur Hom weergebore is, geheilig is, wat deur sy krag gekruisig is, wat deur sy krag tot nuwe lewe opgewek word, wat deur sy krag nou soek wat daarbo is, wat deur Hom geregeer word, wat deur Hom versterk word, wat deur Hom vernuwe en geheilig word, wat al meer met Hom verenig word, ja, wat déél in al sy skatte en gawes - dat hulle onveranderd sal bly lewe." Die lewe van dankbaarheid, dié lewe van gebod en gebed, van dien en aanroep, is daarom "vrug," "vrug van dankbaarheid" (Antwoord 64) en "vrug van die geloof" (Antwoord 86), dit is "hartlike vreugde," "lus en liefde," (Antwoord 90), dit geskied "gewillig en met vreugde" (Antwoord 55), dis die lewe van mense "van harte gewillig en bereid" (Antwoord 1) gemáák.

19. Reg aan die begin van die derde deel verduidelik die Kategismus dan ook presies só.

Vraag 86: Waarom moet ons nog goeie werke doen, terwyl ons tog sonder enige verdienste van ons kant alleen uit genade deur Christus uit ons ellende verlos is?

Antwoord: Omdat Christus ons, nadat Hy ons met sy bloed gekoop het, ook deur sy Heilige Gees tot sy ewebeeld vernuwe sodat ons met ons hele lewe bewys dat ons God dankbaar is vir sy weldade en Hy deur ons geprys word: Verder, sodat ons vir onsself uit die vrugte van ons geloof sekerheid kan kry en ons deur ons godvresende lewe ons naaste ook vir Christus kan wen.

Waarom dan nog goeie werke, vra die Kategismus, as ons "sonder verdienste" "alleen uit genade" uit "ons ellende" verlos is? Omdat Christus ons deur sy Heilige Gees vernuwe, tot sy ewebeeld - dis ons troos.

20. Dis uiteraard ' $\mathrm{n}$ volgende vraag of die Kategismus se logika oortuigend is en inderdaad volgehou kan word teenoor die kritiek, verwyte en beskuldigings - en hóé dit gedoen sou kon word. ${ }^{38}$ In onlangse jare het verskeie teoloë inderdaad - sowel krities as konstruktief ingegaan op hierdie soort logika van Calvyn (en daarmee ook die Kategismus), waar onder byvoorbeeld J. Todd Billings, Kathryn Tanner ${ }^{39}$ en Catherine Pickstock, ${ }^{40}$ benewens die name wat reeds voorheen genoem is. Billings verdedig dit byvoorbeeld deur klem te lê op die deelname aan Christus, in sy Calvin, Participation, and the Gift: The Actvity of Believers in Union with Christ. ${ }^{41}$ Eberhard Busch lê op sy beurt weer uit hoe die Kategismus 'n boodskap van egte

38. Dit is meermale die taal, formulerings en uitdrukkings van die Kategismus wat tot kritiek lei. In die gesprekke oor die vraag of 'n gawe wel denkbaar is, speel temas soos ver-giffe-nis, soos gasvryheid, soos offer, op-offer, self-opoffering, self-verloëning en diensbaarheid meermale ook sleutelrolle, en om begryplike redes is hulle vir vele hedendaagse denkers almal onaanvaarbare terme en handelswyses. Om dié rede is die Kategismus se gebruik van sulke uitdrukkings gevolglik ook meermale uiters omstrede, sien byvoorbeeld die "behoort" van Antwoord 1 (inderdaad dié sleutel tot die hele Kategismus), "onsself as lewende dankoffers aan Christus kan toewy" (Antwoord 32), "onsself as dankoffers aan Hom kan toewy" (Antwoord 43), "verplig om ons gawes tot nut en saligheid van ander aan te wend" (Antwoord 55). Sien die werk van Robert R. Vosloo oor gasvryheid, Engele as Gaste, Wellington: Lux Verbi, 2006.

39. Kathryn Tanner, Jesus, Humanity and the Trinity: A Brief Systematic Theology, Minneapolis: Fortress, 2001; Tanner, Economies of Grace, Minneapolis: Augsburg Fortress, 2005.

40. Catherine Pickstock, After Writing, Oxford: Blackwell, 1998.

41. J. Todd Billings, Calvin, Participation, and the Gift: The Actvity of Believers in Union with Christ,

Oxford: Oxford University Press, 2007. Hy werk implikasies van dié gedagtes vir die kerk daarna verder 
NGTT: Oopbron - http://ngtt.journals.ac.za

vryheid bring, in sy Der Freiheit zugetan (in Engels vertaal as Drawn to Freedom). ${ }^{42}$

Wat egter wel duidelik behoort te wees is dat daar $\mathrm{n}$ beduidende verskil is tussen die Kategismus se eie logika en die populêre maniere waarop die Kategismus in die geskiedenis meermale uitgelê, verstaan en gebruik is. Die werkingsgeskiedenis was meermale inderdaad verantwoordelik vir die soort wettiese en moralistiese sienings wat vandag allerweë gekritiseer word as $\mathrm{n}$ soort uitruil-logika, in stryd met die gedagte van genade, vrye guns en egte gawes. ${ }^{43}$

Miskien kan 'n mens selfs sê dat die uitleg-tradisie en die werkingsgeskiedenis ons self van die Kategismus se eie troos vervreem het - en dat dit dalk as ' $\mathrm{n}$ verrassende gawe en welkome geskenk in vele Gereformeerde kringe beleef mag word indien ons oë in hierdie jaar van die 450ste herdenking opnuut geopen word vir die geestelike logika van die Heidelbergse Kategismus self.

\section{KEY WORDS}

Heidelberg Catechism

Alienation

Gift

Sin and misery

Gratitude

\section{TREFWOORDE}

Heidelbergse Kategismus

Vervreemding

Gawe

Sonde en ellende

Dankbaarheid

\section{KONTAKBESONDERHEDE}

Prof DJ Smit

Fakulteit Teologie

Privaatsak X1

7602 MATIELAND

Tel (kantoor): 021808 3258; (huis): 021880 1921; E-pos: djs1@sun.ac.za

uit in 'n meer populêre studie, Union with Christ. Reframing Theology and Ministry for the Church, Grand Rapids: Baker Academic, 2011.

42. Busch, in sy Drawn by Freedom (oorspronklike Duitse titel: Der Freiheit zugetan, Neukirchen:

Neukirchener Verlag, 1998) toon aan hoe fundamenteel die motief van vryheid in die Kategismus is, teenoor opvattinge van vryheid wat beweer dat die boodskap van die Kategismus verslawend of wetties sou wees. Hy verduidelik dat die uitdrukking der Freiheit zugetan van Zwingli stam en beteken "God favors freedom." Hy gebruik dan die beeld van Lasarus wat deur Jesus uit die graf na buite geroep word en sê dat die evangelie mense só roep en trek, mense in verbande en doeke en beroof van die lig, word na buite geroep en getrek, om waarlik vry te kan lewe. "This is how a person becomes 'drawn' to freedom and its right use. The title of this book intends to indicate the sum of the message with which the Christian movement is entrusted, and which it is the task of its theology to think through," xi.

43. Onder die gesaghebbende studies van die wet by Calvyn tel I. John Hesselink se Calvin's Concept of the Law, Allison Park: Pickwick Publications, 1992. Hy verdedig ook die diepste motiewe van die Gereformeerde geloof teen die beskuldiginge van wettisisme in sy populêre studie, On Being Reformed: Distinctive Characteristics and Common Misunderstandings, Servant Books, 1983. Sien ook sy "Law and Gospel or Gospel and Law? Karl Barth, Martin Luther and John Calvin," NGTT Deel 51, Vol 1, 2012, asook sy "Sovereign Grace and Human Freedom," NGTT Deel 53, Vol 3 \& 4, 2012, 130-143. 